\title{
The issue of infected false aneurysms in drug addicts
}

\author{
Miroslav Dvořáček, Martin Bernat, Libor Vlček, Zdeněk Pelák \\ Department of Surgery, Královské Vinohrady University Hospital \\ and Charles University School of Medicine 3, Prague, Czech Republic
}

\begin{abstract}
Dvořáček M, Bernat M, Vlček L, Pelák Z (Department of Surgery, Královské Vinohrady University Hospital and Charles University School of Medicine 3, Prague, Czech Republic). The issue of infected false aneurysms in drug addicts. Cor Vasa 2008;50(3):125-128.
\end{abstract}

The aim of the paper is to discuss optimal management of infected femoral artery pseudoaneurysm in intravenous drug addicts. Judging by the relevant literature, there is no doubt that the most experienced vascular surgeons come from the USA and Iran. Still, there has not been unanimity as to the best option for managing lower limb ischemia as a one-stage procedure. Since December 2006, we have treated three such cases in an attempt to save the patient's life and his/her extremity. The socioeconomic aspects of the issue should also not be disregarded.

It seems appropriate to handle each case on an individual basis and to carefully consider revascularization of an infected femoral artery pseudoaneurysm as a one-stage procedure.

Key words: Pseudoaneurysm - Drug addicts - Infection - Ischemia - Bleeding - Thrombosis - Bypass - Amputation

Dvořáček M, Bernat M, Vlček L, Pelák Z (Chirurgická klinika, Fakultní nemocnice Královské Vinohrady a 3. lékařská fakulta Univerzity Karlovy, Praha, Česká republika). Problematika infikovaných falešných výdutí u narkomanů. Cor Vasa 2008;50(3):125-128.

Cílem článku je zamyslet se, jak nejlépe postupovat při řešení komplikací u infikovaných pseudoaneuryzmat u narkomanů. $Z$ dostupné literatury je zřejmé, že největší zkušenosti mají lékaři $z$ USA a Íránu. Přesto neexistuje jednotný názor na řešení ischemie dolní končetiny v první době.

Od prosince 2006 jsme na naší chirurgické klinice ošetřovali tři takové případy, se snahou zachránit život i končetinu pacientovi. Neměli bychom také opomenout socioekonomický pohled na tento problém.

Zdá se, že je vhodné posuzovat každý případ individuálně a pečlivě zvážit cévní rekonstrukci v první době léčby infikované falešné výdutě femorální tepny.

Klíčová slova: Pseudoaneuryzma - Narkomanie - Infekce - Ischemie - Krvácení - Trombóza - Bypass - Amputace

Address: MUDr. Miroslav Dvořáček, Department of Surgery, Královské Vinohrady University Hospital and Charles University School of Medicine 3, Šrobárova 50, 10034 Prague 10, Czech Republic, e-mail: miroslav.dvoracek@post.cz

In recent years, we have been increasingly faced with a major challenge: putting at risk the extremities of patients with false aneurysms of the femoral artery caused by injection administration of addictive substances.

This applies to about $30 \%$ of all the intravenous drug addicts worldwide. ${ }^{(1)} \mathrm{A}$ false aneurysm results from a contaminated injection needle, which causes necrosis in the artery wall and periarterial tissue, which can in turn lead to artery rupture and bleeding. ${ }^{(2-4)}$

The clinical pattern can be described by ischemia of the extremity involved, and acute arterial hemorrhage, always combined with infection in the groin, which considerably complicates the condition.

The outcome of attempts at salvaging the extremity is most unsure.

Since December 2006, at the Department of Surgery of the Královské Vinohrady University Hospital, we have managed three cases of this type: the first resul- ted in high amputation of the femur with complicated stump healing; in the second case, the extremity was salvaged using perfusion through the deep femoral artery and, in the third case, after deferral, an obturating bypass was successfully performed.

Terms: False aneurysm - aneurysma falsum: originating by damage to the arterial wall integrity, where the blood enters the surrounding area, a capsule or false aneurysm wall is formed by thrombotic matter, and the blood flow in the artificially formed space around the artery is maintained.

Complications of a false aneurysm:

1. Thrombosis of the artery involved

2. Bleeding (puncture, infection)

\section{CASE 1}

Patient J. K., 41 years of age, a male drug addict, was admitted in febrile condition in February 2006, due 
to acute symptoms of ischemia of the right distal extremity and a clinical finding of infected false aneurysm in the groin. The patient subjectively suffered from strong pain in the extremity involved. Ultrasound examination was carried out, a pulsing resistance was found at the level of and under the right groin of transverse dimensions about $2.2 \times 1.9 \mathrm{~cm}$ and length up to $3.5 \mathrm{~cm}$; in the surroundings, a considerable hyperechogenic infiltrate, width up to $10 \mathrm{~mm}$, almost circular, the finding corresponded to femoral artery pseudoaneurysm; the femoral vein was difficult to identify.

Blood count: $\mathrm{Hb} 140$, htc 43, leuko 22.4, ery 4.9, thrombo 196, CRP 297, urea 6.9, crea 63, gly 6.3, bili 37, ALT 0.42, AST 0.32, ALP 2.15, GMT 0.76, Na 129, $\mathrm{K} 3.24, \mathrm{Cl} 85$ - baseline laboratory values. Coagulation parameters were within the normal range.

Upon admission, heparin was administered: 10.000 units in i.v. bolus and continuously thereafter; operated after preparation.

Surgical finding: An abscessed false aneurysm of the superficial femoral artery branching. Thrombosis of the superficial and deep femoral arteries; partial thrombosis in the great saphenous vein, bilateral. Severe and extensive necrosis of muscles extended to the femur, necrotic arterial wall with purulent matter in the lumen.

Intervention: Thrombectomy of the superficial and deep femoral arteries, replacement of the superficial artery with a venous graft (great saphenous vein) taken from both distal extremities, necrectomy, lavage, drainage.

Under combined (spinal and general) anesthesia, the external iliac artery on the right side, above the inguinal ligament was first provided with a tube, thereafter preparation under pulsing resistance, visualization of the superficial femoral artery, after that penetration through the abscess and old, smelling hematoma to the bleeding source; systemic administration of heparin 10.000 units, clip above the external iliac artery; bleeding from decayed superficial femoral artery at the branching dorsally, clip. Arteries were isolated in a stepwise manner; the superficial and deep femoral arteries were severely necrotic, of black color, limp consistence, in the gangrene of muscles reaching the bone, which cannot be removed. A tissue sample was taken for bacteriology and a segment of the arterial wall for histology. We continued distally to the vital artery, which was interrupted; with a Fogarty catheter, we had free access under the knee, we removed numerous thrombi and obtained sufficient return. The common femoral artery was isolated on account of cutting the inguinal ligament; the necrotic superficial femoral artery was cut off from the branching. The defect was closed by running suture Prolene 6/0. Clip under the ligament on the common femoral artery, longitudinal arteriotomy, patency of the deep femoral artery with fresh thrombus provided with the Fogarty catheter, thereafter sufficient back inflow was obtained. The great saphenous vein was removed from both distal extremities; it was gracile, with thickened walls. The vein was dilated with the Fogarty catheter and adjusted, and anastomosis sutured end-to-side by running suture Prolene 6/0; the anastomosis was tight. The vein was only partially filled and thus, the dilatation was improved using the Fogarty catheter. A second graft was sutured, veno-venous anastomosis was created with running suture Prolen 6/0 end-to-end, patent. Adjustment of ends of the graft and artery, anastomosis end-to-end sutured by running suture Prolene 6/0, after releasing clips, the reconstruction was patent.

Surgical outcome: Early closure of the reconstruction due to a graft of poor quality. All the attainable veins of the patient were destroyed by long-term use of drugs.

Further postoperative course: On the ensuing days, due to compartment syndrome, fasciotomy was carried out on the anterior and inner aspects of the leg; progression of the ischemia, development of gangrene of the right extremity distal toes. The patient was indicated for femur amputation, which was carried out with further necrectomy in the groin. Healing of the stump was complicated, per secundam. The hospitalization was completed after 42 days by discharging the patient to receive home care. Further treatment and additional healing of the stump was provided within outpatient care, the patient healed per secundam.

\section{Histology}

Part of the vessel $35 \mathrm{~mm}$ long, $7 \mathrm{~mm}$ in diameter, wall $2 \mathrm{~mm}$.

Microscopically, this is a muscular-type artery, the artery wall in certain blocks was infiltrated with granulocytes, but without fibrinoid necrosis.

In some of the blocks, particularly in the area of one of edges of the vessel, necrosis of the whole vessel was present with adjacent, partially organized thrombosis.

In the region of the necrotic elastic internal and external wall membrane, there was also focal disintegration. In the central part of the excision, an artery in the external third of the tunica media defect was present, formed by necrotic matter, partially penetrated with blood, reminding of dissection; florid, inflammatory exudation in the margin of the defect area.

Group F Streptococcus, sensitive to amoxicillin and clindamycin, was cultured perioperatively from the wound.

\section{CASE 2}

Patient P. J., a woman 23 years of age, a drug addict, emergency admission in December 2006 for manifestation of an abscess in the right groin after injection administration of an addictive substance; febrile condition $40^{\circ} \mathrm{C}$. No manifestations of ischemia or hemorrhage were noted on admission.

Ultrasound examination of the groin: A voluminous vaguely delimited infiltration was present within the resistance range of the right groin. Several vaguely delimited hypoechogeneities of up to $2 \mathrm{~cm}$ were noted, which may have been consistent with incipient colliquation, but without unambiguous abscess formation. The femoral vessel was freely patent to the extent of the infiltrate. In the assumed extension of the saphenous vein, a hypoechogenic strip was vizualized, 


\begin{tabular}{|c|c|c|c|c|c|c|c|}
\hline & $\begin{array}{l}\text { Primary } \\
\text { infection }\end{array}$ & $\begin{array}{l}\text { Primary } \\
\text { ischemia }\end{array}$ & $\begin{array}{l}\text { Bleeding before } \\
\text { /after surgery }\end{array}$ & $\begin{array}{c}\text { Early closure } \\
\text { of reconstruction }\end{array}$ & $\begin{array}{l}\text { Healing } \\
\text { per sec. }\end{array}$ & Re-operation & Amputation \\
\hline Patient 1 & + & + & & + & + & + & + \\
\hline Patient 2 & + & & + & + & + & + & \\
\hline Patient 3 & + & & $+/+$ & & + & + & \\
\hline
\end{tabular}

which most likely corresponded to a thrombotic/ inflammatory vein at the site of the outlet.

Baseline laboratory values: $\mathrm{Hb} 138$, htc 40, leuko 27 , ery 4.92 , thrombo 379 , INR 1.27 , APTT within normal range, urea 2.3, gly 8.6, bili 9.2, ALT a AST within normal range, Na 135, K 3.4, CRP 204.

Surgical finding: Infected false aneurysm of the branching of the right superficial femoral artery with loss-making defect of the posterior wall of about $3 \mathrm{~cm}$. Partial thrombosis of the great saphenous vein.

Intervention: Replacement of the branching of the superficial femoral artery with a venous graft (great saphenous vein). Anastomoses end-to-end, necrotomy, lavage and drainage.

The postoperative period was complicated by early thrombosis of the reconstruction due to poor quality of the venous graft; healing per secundam. The closure was verified by ultrasound examination. Bleeding from the wound occurred one week post surgery and the patient was immediately operated on. The source of the bleeding was in the region of the arteriovenous anastomosis. The graft was removed and the superficial femoral artery was ligated immediately under the branching of the bifurcation of the common femoral artery. Ultrasound examination of other superficial veins was carried out and a small older thrombosis of both the great and small saphenous veins of distal extremities was demonstrated. The extremity temperature was maintained, without symptoms of ischemia. The patient was discharged; further treatment was provided within the scope of outpatient care. After complete healing in the groin, possible further vascular reconstruction was planned; the patient had her last follow-up visit in March 2007, when she reported right fibular claudication after $100 \mathrm{~m}$, but she did not visit the vascular outpatient counseling center any more. The further fate of the patient is unknown.

Culture from the wound: E. coli, sensitive to co-trimoxazole, ciprofloxacin, gentamycin, chloramphenicol; Staphylococcus aureus sensitive to oxacillin.

\section{CASE 3}

Patient M. J., male 30 years of age, a drug addict, hepatitis C, emergency admission on 4 June 2007 for arterial bleeding from the right groin, caused by the patient himself, who cut an infected focus.

Admission laboratory results: $\mathrm{Hb} 73$, htc 21, leuko 29.6, ery 2.5, thrombo 252.

INR 1.38 , APTT $44.7 / 34$, urea 2.8 , gly 7.8 , bili 11.8 , ALP 2.52, GMT 0.55, ALT 0.67, AST 0.55, Na 132, $\mathrm{K} 3.54, \mathrm{Cl} 95$
Surgical finding: Abscessed false aneurysm. Lesion of the common and superficial femoral arteries, obliteration of the deep femoral artery; partial thrombosis of the right great saphenous vein.

Intervention: Evacuation of the abscess, replacement of the common and superficial femoral arteries with vein, ligation of the deep femoral artery.

Histology of the artery wall: Purulent, necrotizing arteritis

Postoperative course: The reconstruction patent; a palpable dorsal artery of the foot. Healing per secundam, subfebrile condition, the patient signed a statement and went home after three weeks of hospitalization.

On the next day, he returned because of new bleeding from the groin; emergency surgery.

Surgical finding: Bleeding in the region of the lower anastomosis. A defect of about $2 \mathrm{~mm}$ on the graft was sutured. Two days later, the bleeding recurred; revision with a suture of the graft defect, that time at another site.

On 29 June 2007, bypass iliacofemoral obturator with prosthesis. Ligation and partial resection of the infected venous graft in the groin.

Under general anesthesia, extended alternate cut in the right meso- and hypogastrium; pelvic arteries were loosened; they were free of sclerotic lesions. From a longitudinal incision on the median side of the right femur, the superficial femoral artery was isolated in the region of the canalis vastoadductorius; it was also free of major sclerotic lesions. Through the foramen obturatorium and between the adductors, tunnelization was carried out between the two wounds and an uncompressible collagen vascular prosthesis, $8 \mathrm{~mm}$, was inserted. Systemic administration of heparin was provided, clips were applied and upper anastomosis was sutured at the end of the prosthesis to the side of the pelvic artery immediately after its bifurcation; distally, also, anastomosis by the end of the graft to the side of the superficial femoral artery. Systemic administration of protamine was provided; clips were released and pulse on the superficial femoral artery resumed. Upon completing the intervention, the infected venous graft localized in the wound in the groin at its both anastomoses was ligated and partially resected.

The ensuing course was uneventful, the wound healed, pulsation was palpable up to the periphery. The patient was discharged to receive home care. $\mathrm{He}$ did not come for follow-up.

Intraoperative culture from the wound: Staphylococcus aureus sensitive to ofloxacin. 


\section{DISCUSSION AND CONCLUSION}

Intravenous use of drugs is associated with increasing complication rates. ${ }^{(2-4)}$ One of these complications is formation of femoral artery false aneurysms. All cases reported to date have been complicated by infection. The surgeon primarily manages infection in the groin or, possibly, acute arterial bleeding or ischemia in the vascular bed of the artery involved.

When these patients first appeared in the 1980's, it seemed to be necessary to carry out artery ligation and vascular reconstruction for the severe ischemia of the extremity. The rates of graft infections do not come as a surprise and the results were generally not optimistic. ${ }^{(3)}$ It is just the infection which is the limiting factor in vascular surgery. There is always a risk that the attempts to salvage the extremity would end up in its amputation. The condition precludes the use of artificial vascular prostheses in the first period and, judging by experience, the use of a venous graft and initiation of radical antibiotic therapy is no guarantee that the infection in the region of the vascular reconstruction will be managed. The vascular anastomoses involved by the infection can bleed, thus endangering the patient life. ${ }^{(4)}$ Unfortunately, the veins of drug addicts are mostly destroyed by permanent intravenous administration of drugs. ${ }^{(5)}$

It should be noted that the new bypass is an easy site for further administration of drugs and, hence, also development of infection, intravascular sepsis, putting the patient at risk of bleeding and death. ${ }^{(4,5)}$

Some international authors do not recommend primary revascularization and are satisfied with surgical treatment of the infection and resection of the false aneurysm with femoral artery ligation. ${ }^{(4,6)}$ The outcomes suggest that the extremity is typically not lost, the ischemia is pronounced only transiently and, according to some reports, the patients report only claudication. Experience reported by other authors indicates that if the common femoral artery must be ligated and early vascular reconstruction is not carried out, amputation is required in as much as $33 \%$ of cases. ${ }^{(4)}$

\section{CONCLUSION}

The physicians attempt to save the patient's life and salvage his/her extremity. In the first period, we treat the infectious focus including extensive necrectomy, debridement, resection of the false aneurysm and ligation of the artery and, possibly, also drainage. ${ }^{(4)}$ The extremity perfusion depends on the site of the artery ligation. After healing of the groin, in the second period, it is possible to carry out final vascular reconstruction, also with the use of an artificial vascular prosthesis.

The method of the primary treatment of the infected false aneurysm is clear. The question of vascular reconstruction in the first period remains open, the results being controversial and the opinions being different.

\section{REFERENCES}

1. Ebright JR, Pieper B. Skin and soft tissue infections in inj. drug users. Infect Dis Clin N Am 2002;16:697-712.

2. Coughlin PA, Mavor AID. Arterial consequences of recreational drug use. Eur Vasc Surg 2006;32:389-96.

3. Gan JP, Lieberman DP, Pollock JG. Outcome after ligation of infected false femoral aneurysms in intravenous drug abusers. Eur Vasc Surg 2000;19:158-61.

4. Albert CW, Ting MD, Stephen WK, Cheng MD. Femoral pseudoaneurysms in drug addicts. World J Surg 1997; 21:783-7.

5. Chan YC, Burnand KG. Management of septic groin complications and infected femoral false aneurysms in intravenous drug abusers. Br J Surg 2006;93:781-2.

6. Naqi SA, Khan HM, Akhtar S, Shah TA. Femoral pseudoaneurysm in drug addicts - excision without revascularisation is a viable option. Eur J Vasc Surg 2006;31: 585-7.

Received 10 December 2007

Accepted 16 January 2008 